\title{
IS DEBT WAIVER A RIGHT SOLUTION TO FARMERS SUICIDE?
}

\author{
*Mrs.Vinaya.L **Dr.Sureshramana Mayya.P
}

\begin{abstract}
:
As per the estimates revealed by Central Statistics office the total share of Agriculture and Allied sectors in terms of GDP is 13.9\% during 2013-14, where more than 48.9\% of India's population depend on Agricultural sector. Farmers risk in his occupation varies from small, marginal and large farmer's from one village to another, one district to another and one state to another state. But the policies framed by the central government remains to be the same irrespective of changes in the amount and extent to which the risk is taken by the individual farmer. Moreover the outreach of the scheme is not for the affected farmers on one side and on another side prompt loan payers show regret for this scheme. One such scheme introduced by the Government is the Debt Waiver Scheme. Is this scheme really useful to the farmers? Or is there any other probable solution for the problems being faced by farmers?
\end{abstract}

Keywords : Debt waiver, Farmer's suicide, Karnataka, Problems, Shivamogga

Objective: Any system that fosters the expectations of a loan waiver is not conducive for building a healthy financial system in a country. Hence an attempt has been made through this article to find, whether debt waiver is the right solution to farmers' problems by analysing the causes for his suicide.

\section{Introduction:}

\section{Debt Waiver Scheme in India}

The Government of India both at the State level and Central level announce the Debt Waiver and Debt Relief Scheme for farmers from time to time. This scheme covers direct agricultural loans which are extended to the marginal, small and other farmers usually through the assistance of Scheduled Commercial Banks, Regional Rural Banks, Cooperative Credit Institutions (including Urban Cooperative Banks) and Local Area Banks. Here Cooperative Credit Institution means a cooperative society that provides short-term crop loans to farmers and is eligible for interest subvention from the Central Government; or carries on banking activities regulated or supervised by Reserve Bank of India or National Bank for Agriculture and Rural Development or is part of the short-term Cooperative Credit Structure or long-term Cooperative Credit Structure in a State or Union Territory.

\section{Farmers Suicide in India- Statistics for $\mathbf{2 0 1 4}$}

India is an agrarian country with around $48.9 \%$ of its people depending directly or indirectly upon agriculture. Nowadays the problem of farmers' suicides is one of the vital concerns that need to be addressed by the Government. Considering the paramount importance of this

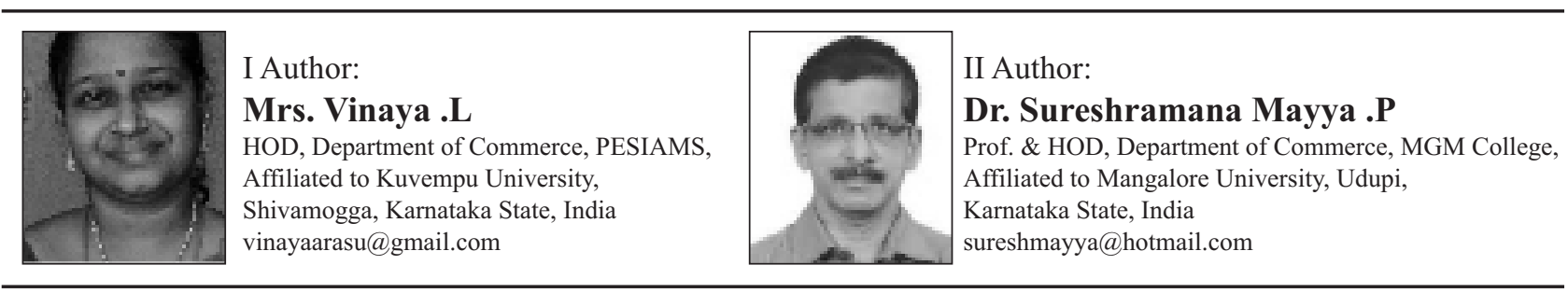


issue, the National Crime Records Bureau (NCRB), for the first time, has collected detailed data on farmers' suicides. Farmers include those who own and work on field (viz. cultivators) as well as those who employ/hire workers for field work/farming activities. It excludes agricultural labourers. A total of 5,650 farmers have committed suicides during 2014, accounting for $4.3 \%$ of total suicides victims in the country. And it is quite Astonishing to see that farmers' death due to Bankruptcy and Indebtedness $(20.58 \%)$ is almost equal to the cause due to family problems $(20.08 \%)$.[1] The information related to this data has been presented below:

Table 1 - Showing Percentage of Causes for Farmers suicides in India during 2014

\begin{tabular}{|c|l|c|c|c|c|}
\hline S1.No. & Cause & Male & Female & Total & $\begin{array}{c}(\%) \text { share of } \\
\text { the causes }\end{array}$ \\
\hline 1. & Poverty & 140 & 9 & 149 & 2.63 \\
\hline 2. & Property Dispute & 52 & 0 & 52 & 0.92 \\
\hline 3. & Marriage Related Issues & 63 & 58 & 121 & 2.14 \\
\hline 4. & Family Problems & 1038 & 97 & 1135 & 20.08 \\
\hline 5. & Farming related Issues & 868 & 101 & 969 & 17.15 \\
\hline 6. & Illness & 682 & 63 & 745 & 13.18 \\
\hline 7. & Drug Abuse/Alcoholic Addiction & 250 & 0 & 250 & 4.42 \\
\hline 8. & Fall in social Reputation & 6 & 1 & 7 & 0.12 \\
\hline 9. & Bankruptcy or Indebtedness & 1112 & 51 & 1163 & 20.58 \\
\hline 10. & Causes not Known & 208 & 23 & 231 & 4.08 \\
\hline 11. & Other Causes & 759 & 69 & 828 & 14.65 \\
\hline 12. & Total & 5178 & 472 & 5650 & 100.00 \\
\hline
\end{tabular}

\section{Source: NCRB Report 2014}

The above table clearly shows that farmers suicide due to Borrowings from

Banks account to only $20 \%$ of the total number of suicides in India.

\section{Debt Waiver Scheme in Karnataka:}

The State government had released Rs 2,878.19 crores during the year 2012 to co-operative institutions for implementation of the cooperative farm loan waiver scheme, announced by the previous BJP government headed by the Chief Minister Jagadish Shettar yielding to the pressure mounted by Sri.B.S.Yediyurappa. The government of Karnataka had announced the loan waiver scheme in its budget for the financial year 2012-13. In this scheme, the crop loan principal upto Rs.25000 including interest on it is waived off to those farmers who have availed crop loan during 01.08.2011 to
25.07.2012 from co-operative institutions. The Estimated benefit and number of estimated beneficiaries from the scheme relieve the farmers of their loan burden who have suffered on account of drought in the State. The budget provision of Rs. 1140.00 crores was made of which Rs.940.00 crores had been released to the co-operative institutions immediately in favour of 4.03 lakh farmer members. During the year 2013-14 out of the budget provision of Rs.2338.65 crores, the Government had released the entire amount, which has in turn benefitted around 10.61 lakh farmer members. Further during 2014- 15, the budget provision 
of Rs. 4.73 crores has been released to 1,832 lakh beneficiaries. In the Financial year 201516 state Government has planned for a Loan waiver for failed borewells through PCARD Banks. The Budget provision is Rs.200 lakhs and subsidized pattern of assistance to be provided to the Co-operative farmers in the Annual plan 2015-16.

\section{Farmer Suicides in Karnataka:}

When Government both Central and State, are providing useful schemes to the beneficiaries, i.e. farmers, either it is insufficient or it is inefficient to meet their requirements. Because it is very clear from the statistics of the National Crime Record Bureau since 2004, 47 farmers have been committing suicide every day in India on an average. However, the recent wave of suicides with forty six farmers killing themselves every day in Karnataka alone demonstrates the severity of the crisis. The last crisis of this nature took place between December 1997 and June 1998, when 400 farmers committed suicide in Karnataka and
Andhra Pradesh due to failure of cotton crop. Dr.Veeresh, who headed a seven-member expert committee to study farmer suicides and submitted the report in 2002, said that "mass psychology" has been confined to sugarcane areas only. "We had done an in-depth study and had specifically recommended that each hospital in a rural area should have a psychiatrist to identify the affected farmers and the ones with suspected suicidal tendencies. When one farmer commits suicide, people talk and it has a psychological effect on others in the same situation," he said. He also said that there was no single issue which led to farmers' suicides. A combination of factors such as delayed payments, low prices, and debt was responsible for this. And "We had given 24 recommendations to address the farmers' problems, but very few have been implemented. The present issue is confined to sugarcane areas and the government has completely failed and passed the buck by constituting one more committee" [2]

Farmers' Suicide and Debt Waiver Scheme in Karnataka-A Comparison: The top ten beneficiaries to the Debt Waiver scheme 2014 and the suicide statistics for 2015 are presented below:

Table 2 - Showing comparative Statistics for Farmers' Suicide and Debt Waiver Scheme

\begin{tabular}{|c|c|c|c|}
\hline S1. No. & District & $\begin{array}{c}\text { Debt Waiver Amount - 2014 } \\
\text { (Rs. In ten crores) }\end{array}$ & $\begin{array}{c}\text { Number of suicides } \\
\text { (Six months highest } \\
\text { record) - 2015 }\end{array}$ \\
\hline 1 & Belgaum & 45.171 & 29 \\
\hline 2 & Bijapur & 33.846 & 15 \\
\hline 3 & Bagalkot & 30.648 & 12 \\
\hline 4 & Bidar & 22.256 & 12 \\
\hline 5 & Hassan & 14.9 & 25 \\
\hline 6 & Shivamogga & 14.3 & 14 \\
\hline 7 & Dakshina Kannada & 14.3 & 4 \\
\hline 8 & Kolar & 0.782 & 9 \\
\hline 9 & Chickballapur & 0.826 & 10 \\
\hline 10 & Chamrajnagar & 1.74 & 134 \\
\hline & Total & 178.769 & \\
\hline
\end{tabular}

Source: Vijayakarnataka Newspaper ${ }^{[3]}$ 
From the above table we can analyse in some of the Districts viz. Belgaum, Hassan, Bijapur and Shivamogga inspite of the maximum debt waiver scheme benefit received, the suicides are mounting which recommends the fact that debt waiver is not the solution to stop farmers from committing suicide. Also there is a mismatch between the Loan waiver scheme amount distribution and farmers' suicides in Karnataka. Mandya, Haveri, Tumkur and Mysore District with highest number of suicides reported, requires the maximum benefit of Loan waiver scheme which is absent in the State Annual Budget 2015-16. Hassan also requires more attention along with Shivamogga, Kolar, Chickballapur and Chamrajnagar. While Belgaum, Bijapur, Bagalkot and Bidar districts, where the co-operative movement is strong, are the largest beneficiaries of the loan waiver scheme. Inspite of the highest beneficiary of the Debt waiver scheme shared by Belgaum it has been in the fifth position in suicides with the number twenty nine to its record which is represented in the below shown table:

Table 3 - Showing Farmers' suicides statistics for topmost ten Districts in Karnataka State

\begin{tabular}{|c|c|c|}
\hline Sl. No. & District & No. of Suicides \\
\hline 1 & Mandya & 56 \\
\hline 2 & Haveri & 44 \\
\hline 3 & Tumkur & 36 \\
\hline 4 & Mysore & 33 \\
\hline 5 & Belgaum & 29 \\
\hline 6 & Hassan & 25 \\
\hline 7 & Davangere & 24 \\
\hline 8 & Gadag & 23 \\
\hline 9 & Chickmagalur & 23 \\
\hline 10 & Raichur & 22 \\
\hline & Total & 315 \\
\hline
\end{tabular}

Source: Vijayakarnataka Newspaper ${ }^{[3]}$

\section{Review of Literature:}

$>$ Looking at the present status of rural banking (the reach, the delays, the procedures and the costs involved in getting a loan), the moneylenders would continue to be in business for quite some time to come and a regular "debt redemption scheme" would be useful. The high indebtedness of the Indian farmer is a manifestation of the neglect and inadequate investment in agriculture. The small and marginal farmers who form the overwhelming percentage of Indian farmers' households are the worst sufferers. Most of them are continuing in agriculture because of the complete absence of any alternative. Improvement in credit delivery would help but more important is a correction in our planning strategies. Among the various suggestions given in this paper the most important steps would be the one-time settlement/compromise for non- willful defaulters, improvement in risk mitigation arrangements, constitution of the agriculture relief fund, improving the functioning of the agricultural credit 
societies, protecting farmers from distress sale and implementation of liberal debt redemption schemes. (Balasaheb Vikhe Patil) ${ }^{[4]}$

$>$ The state should ensure the creation of an environment which supports effective financial intermediation and increases the access of farmers to financial services. It also has to facilitate the enforcement of collateral mechanism and ensure easy access to land records and other titles through computerization. The state has also to unshackle the cooperative credit system by debureaucratisation and depoliticisation, in tune with the recommendations of the Vaidyanathan Committee. (P.Satish) ${ }^{[5]}$

$>$ The farm loan waiver must be seen as purely temporary relief and there must be programmes to improve agriculture. There are many exclusions and limitations to the loan waiver scheme. It is possible that there may be discontent among 80 per cent of the farmer households who are excluded from the scheme. This huge thrust is needed for other core issues so that the farmers do not fall back into a debt trap, needing another loan waiver in the next few years. The finance minister could have attempted this big push to agriculture on the back of buoyant tax revenues. (S Mahendra Dev) ${ }^{[6]}$

$>$ Life histories of suicide victims are equally far too complex to be exclusively reduced to agrarian economics. Farmers' suicides appear as a unitary object only as a contentious representation: as a political scandal in the critical media, among activists and politicians. (Daniel Munster $)^{[7]}$
$>$ The whole scheme is sure to create discontentment amongst a large section of the farming community. In the first place, it will benefit only those who carry overdue loans for willful or non-willful reasons. Vast segments of farmers prefer to repay their loans and they will not get any benefit. Another sizeable category - over 50 per cent of the indebted category borrows from moneylenders and other non-institutional agencies, which will also not get any respite. And finally, if the NSSO data are to be believed, more than one-half of the total farmer households46 million out of 89 million - are not indebted to any agency, official or nonofficial, but their sufferance due to the farm crisis cited earlier is as acute as in the case of the indebted farmers and their agonizing survival will persist all the more because the government has parted with as much as Rs 60,000 crore on loan waivers and not on badly needed developmental programmes. (EPF Research Foundation) ${ }^{[8]}$

\section{An Analysis of Farmers' Suicides in Shivamogga District:}

If Indebtedness and Bankruptcy are the main reasons for the farmers to commit suicide and the farmers' are demanding a debt waiver as a solution for this, to what extent is it true? And also the question is whether Debt waiver scheme is providing the relief to farmers from their problems or not. If yes then why farmers are committing suicide? If no, then who are encashing the benefits of the scheme? To answer these questions, the data related to the farmers suicides in Shivamogga District for the year 2009 to 2016 has been collected which may through some realistic light on this issue and give us the pros and cons of this scheme. 
Table 4 - Showing Year wise Statistics of Suicides in Shivamogga District from 2009 to 2016

\begin{tabular}{|l|l|c|c|c|c|c|c|c|c|}
\hline \multicolumn{7}{|c|}{ Year wise distribution of suicides in Shivamogga district from 2009 to 2016} \\
\hline $\begin{array}{c}\text { Sl. } \\
\text { No }\end{array}$ & \multicolumn{1}{|c|}{ Taluk } & $09-10$ & $10-11$ & $11-12$ & $12-13$ & $13-14$ & $14-15$ & $15-16^{*}$ & TOTAL \\
\hline 1. & Shivamogga & 2 & 1 & 0 & 0 & 0 & 5 & 5 & 13 \\
\hline 2. & Bhadravathi & 5 & 2 & 1 & 0 & 1 & 2 & 0 & 11 \\
\hline 3. & Thirthahalli & 6 & 3 & 7 & 2 & 5 & 4 & 0 & 27 \\
\hline 4. & Sagar & 0 & 0 & 0 & 0 & 0 & 2 & 2 & 4 \\
\hline 5. & Hosanagar & 0 & 0 & 0 & 0 & 1 & 0 & 1 & 2 \\
\hline 6. & Shikaripur & 2 & 1 & 0 & 2 & 1 & 0 & 3 & 9 \\
\hline 7. & Soraba & 0 & 2 & 0 & 3 & 3 & 0 & 3 & 11 \\
\hline & Total & 15 & 9 & 8 & 7 & 11 & 13 & 14 & 77 \\
\hline
\end{tabular}

Source: DC office Report ${ }^{[9]}$

*Data till April 2015 for 2015-16 (All reported cases pending)

Graph 1 - Showing Farmers suicides in Shivamogga District Taluk Wise for the year 2009-10 to 2015-16

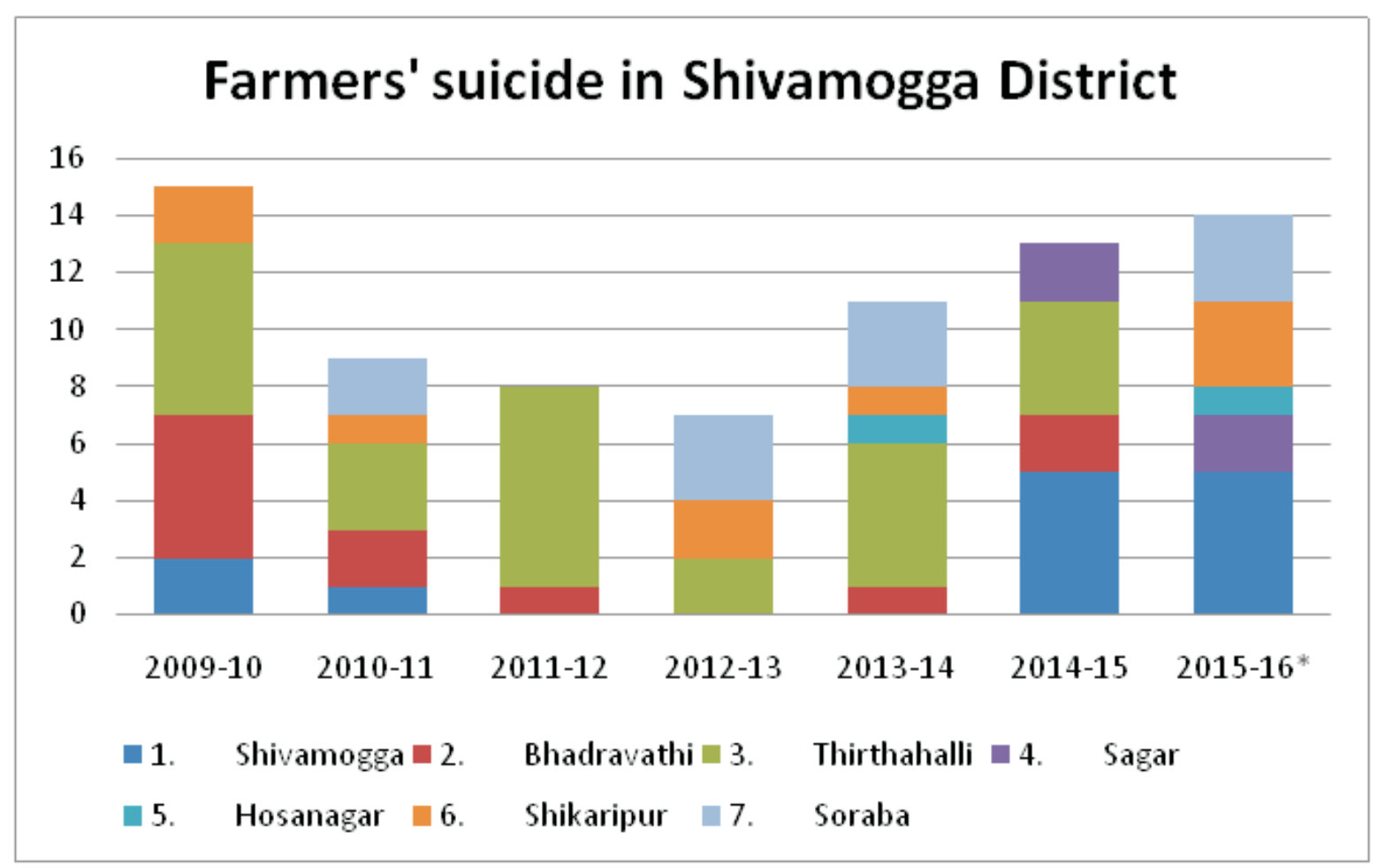


Table 5 - Showing Year-wise Statistics of Farmers' suicide causes in Shivamogga District from 2009-10 to 2014-15

\begin{tabular}{|l|l|c|c|c|c|c|c|c|}
\hline \multicolumn{8}{|c|}{ Year-wise distribution of causes for farmers' suicide in Shivamogga District 2009-10 to 2014-15 } \\
\hline $\begin{array}{l}\text { Sl. } \\
\text { No }\end{array}$ & Causes-Confirmed by DC & $09-10$ & $10-11$ & $11-12$ & $12-13$ & $13-14$ & $14-15$ & Total \\
\hline 1 & Crop Loan & 8 & 2 & 4 & 0 & 2 & 4 & 20 \\
\hline 2 & $\begin{array}{l}\text { Marriage Related } \\
\text { Issues/Family Problems }\end{array}$ & 6 & 5 & 4 & 0 & 1 & 0 & 16 \\
\hline 3 & Causes not Known & 1 & 1 & 0 & 3 & 1 & 2 & 8 \\
\hline 4 & $\begin{array}{l}\text { Cases Pending -Insufficient } \\
\text { Evidence }\end{array}$ & 0 & 0 & 0 & 0 & 1 & 5 & 6 \\
\hline 5 & Mental Illness/Diseases & 0 & 0 & 0 & 1 & 3 & 0 & 4 \\
\hline 6 & Vehicle Loan / Gold Loan & 0 & 0 & 0 & 1 & 2 & 0 & 3 \\
\hline 7 & $\begin{array}{l}\text { Post-Mortem Report } \\
\text { Awaited }\end{array}$ & 0 & 0 & 0 & 1 & 0 & 1 & 2 \\
\hline 8 & Rejected-False Evidence & 0 & 0 & 0 & 1 & 1 & 0 & 2 \\
\hline 9 & Loss due to Crop Failure & 0 & 0 & 0 & 0 & 0 & 1 & 1 \\
\hline 10 & $\begin{array}{l}\text { Drug Abuse/Alcoholic } \\
\text { Addiction }\end{array}$ & 0 & 1 & 0 & 0 & 0 & 0 & 1 \\
\hline 11 & Total & 15 & 9 & 8 & 7 & 11 & 13 & 63 \\
\hline
\end{tabular}

Source: DC office Report ${ }^{|9|}$

\section{Major Findings:}

$\checkmark$ Thirthahalli District stands first with highest number of suicides (27) out of total suicides in Shivamogga District from the year 2009-10 to April 2015.

$\checkmark 20$ cases out of the Total 63 reported were confirmed due to Debt burden (Crop Loan) whereas 16 cases have been confirmed suicide cases due to family problems.

$\checkmark$ The cases reported take at least two years to provide sufficient evidence and get confirmed by the DC.

$\checkmark$ The total number of farmers' suicides shows a decreasing trend from 2009-10 to 2012-13 and later has increased.

$\checkmark$ Out of the total suicide cases, all the cases reported during 2015-16 upto April 2015 are pending as the reasons for suicides are not updated in the DC office Report.

$\checkmark$ The total number of suicides is increasing but the reason for that, it is due to crop loan has decreased considerably from the year 2009 to 2015 .

\section{Hence it is very clear that:}

* Farmers' suicides are not caused mainly due to indebtedness or Bankruptcy.

* If Indebtedness and Bankruptcy are the reasons then Debt Waiver scheme is not the probable solution expected by the farmers.

* If Debt waiver scheme is announced it is not efficiently monitored by the Government Authorities.

\section{Recommendations}

Debt Burden whereas more number of suicides committed by the farmers are due to family problems, mental illness and loans borrowed to satisfy their personal needs rather than using them for agricultural purpose. Hence it is difficult to justify the benefits of Debt waiver scheme to the beneficiaries of this occupation 
.Thirthahalli District stands first with highest number of suicides i.e. 27 out of 77 suicides in Shivamogga District for the period of seven years from 2009-10 to 2015-16.

Debt waivers don't increase Agricultural productivity: It may not motivate the farmers to produce more rather encourages nonrepayment of the debt already borrowed from the Government for agricultural purpose in spite of their comfortable capacity zone to do so.

Debt Waiver scheme benefits do not reach the right beneficiaries: There is no proper directions issued to make the loan waiver benefits reach the farmers who are really in need of the scheme and influential hands do not pave way for the appropriate usage of the benefits under this scheme.

Small, Marginal and Large farmers not distinguished: All though the scheme suggest that marginal and small farmers to be benefitted from the Government schemes to overcome their debt burden, to what extent the officials disbursing the scheme amount justify to this context is basically a nightmare to the farmers. On the contrary part of it marginal farmers may suffer loss more than that of the small farmers which may not be taken into consideration under the scheme.

No importance for prompt repayment of loan: The farmers who have made a prompt payment upto date find fewer benefits from those who have not repaid a single rupee. Hence they may feel penalized for their prompt Act and get demotivated for repaying the loan borrowed from the Banks.

Efficient team to monitor at village level: The policy framed at the Central or State Level is not sufficient, it also requires an ethical and efficient team to carry out the activities as prescribed in the Governmental Scheme and help the right beneficiaries to claim their benefits.

Time taken for disbursement of fund is always an issue: Although Government releases a huge amount of fund to waive of the Debt of the needy farmers, it does not reach him at the right time. The long and complicated process basically causes delay and thereby farmers are unable to bear the heavy debt burden, as a reason for which some of them make wrong decisions to end their life.

Just a political Instrument: From another point of view Debt waiver Scheme seems to be considered as a political instrument working out for an vote bank scheme or an eyewash technique of the Government to make the people feel they are being taken care of as it is not the right solution to the problems of the farmers.

\section{Conclusion}

978 farmers have committed suicide across Karnataka during the month of April to December in the year 2015 where low price for the agricultural produce and absence of timely and adequate debts are main reasons behind it. Most of the farmers who ended their lives in Mandya District are sugarcane growers. Maximum deaths have been reported from the districts of Mandya (92), Belgaum (74), Haveri (73), Mysore (62), Hassan (58) and Tumkur (56). But there is a different line of apportionment for the Debt waiver Scheme. It is a known fact that farmers' indebtedness is only a symptom, there are many other issues like reduced overall growth of agriculture, declining productivity, profitablity which has been responsible for all the above problems. Our failure to promote rural industrialisation and other non-farm activities, many of our small and marginal farmers have to depend on the low productivity agriculture. This debt waiver policy is against the principle of promoting healthy and strong financial system. 
It is against the systematic method of institutionalizing the enforcement of credit granted through developed policy guidelines by the state as well as central Government. The right solution to farmers' problems is not Debt Waiver or a Debt Relief Fund, rather creating opportunities for them to convert their Investment towards agricultural produce into profitable one by providing good marketing and warehousing facilities, fixing a stable support price, crop insurance, efficient monitoring and evaluation by lending institutions etc.

\section{References:}

1. Suicide in India, NCRB Report retrieved on 27th August 2015 at 3.40 p.m from www.ncrb.gov.in

2. Suicides in Karnataka, A Report by Dr. G.K. Veeresh retrieved on 26th August 2015 at 3.00 p.m from www.newindianexpress.com

3. District wise Statistics for farmers' suicides in Karnataka retrieved on 10th September 2015 at 3.00 p.m from www.VijayaKarnatakapaper.com
4. Agricultural Indebtedness: Crisis and Revival, Balasaheb Vikhe Patil, Economic \& Political Weekly, pg.52, February 2nd 2008

5. Institutional Credit, Indebtedness and Suicides in Punjab, P.Satish Economic \& Political Weekly, pg.2761, June 30th 2006

6. Agriculture: Absence of a Big Push, S Mahendra Dev, Economic \& Political Weekly, pg.36, April 12th 2008

7. Farmers' suicides and the state in India: Conceptual and ethnographic notes from Wayanad, Kerala: Contributions to Indian Sociology 46, 1\&2 (2012): 181-208/ Daniel Muster, Downloaded from cis.sagepub.com at Universiti Teknologi MARA (UiTM) December 25th 2015

8. EPW Research Foundation, Economic \& Political Weekly, pg.30, March 15th 2008

9. Taluk wise Statistics for farmers' suicides and their causes in Shivamogga District Records of DC Office Report from 2009 to 2015 